\title{
Recent Advances in Rare Earth Complexes Containing N-Heterocyclic Carbenes: Synthesis, Reactivity, and Applications in Polymerization
}

\author{
Yu Pan ${ }^{1} \mathbb{D}$, Xinxin Jiang ${ }^{1}$, Yat-Ming So ${ }^{2, *}$, Ching Tat To $^{3 \oplus}$ and Gaohong He ${ }^{1, *}$ \\ 1 State Key Laboratory of Fine Chemicals, School of Petroleum and Chemical Engineering, Dalian University \\ of Technology, Panjin 124221, China; ypan@dlut.edu.cn (Y.P.); jiangxinxin1996@foxmail.com (X.J.) \\ 2 Department of Chemistry, The Hong Kong University of Science and Technology, Clear Water Bay, Kowloon, \\ Hong Kong, China \\ 3 Department of Chemistry, Tunghai University, No. 1727, Sec. 4, Taiwan Boulevard, Xitun District, \\ Taichung 40704, Taiwan; ctto@go.thu.edu.tw \\ * Correspondence: chsym@connect.ust.hk (Y.-M.S.); hgaohong@dlut.edu.cn (G.H.)
}

Received: 24 November 2019; Accepted: 31 December 2019; Published: 3 January 2020

check for updates

\begin{abstract}
N-heterocyclic carbenes (NHCs) are ubiquitous ancillary ligands employed in metal-catalyzed homogeneous reactions and polymerization reactions. Of significance is the use of NHCs as the supporting ligand in second- and third-generation Grubbs catalysts for their application in olefin metathesis and ring-opening metathesis polymerization. While the applications of transition metal catalysts ligated with NHCs in polymerization chemistry are well-documented, the use of analogous rare earth ( $\mathrm{Ln}=\mathrm{Sc}, \mathrm{Y}, \mathrm{La}, \mathrm{Ce}, \mathrm{Pr}, \mathrm{Nd}, \mathrm{Pm}, \mathrm{Sm}, \mathrm{Eu}, \mathrm{Gd}, \mathrm{Tb}, \mathrm{Dy}, \mathrm{Ho}, \mathrm{Er}, \mathrm{Tm}, \mathrm{Yb}$, and Lu) catalysts in this area remains under-developed, despite the unique role of rare earth elements in regioand stereo-specific (co)polymerization reactions. By using hetero-atom-tethered chelating NHCs and, more recently, the employment of other structurally related NHCs, NHC-ligated Ln complexes have proven to be promising and fruitful catalysts for selective polymerization reactions. This review summarizes the recent developments in the coordination chemistry of Ln complexes containing NHCs and their catalytic performance in polymerization.
\end{abstract}

Keywords: rare earth complex; N-heterocyclic carbene; organometallic chemistry; coordination polymerization; ring opening polymerization

\section{Introduction}

N-heterocyclic carbenes (NHCs) are persistent carbenes and have been demonstrated to be versatile ancillary ligands for metal-based catalytic reactions [1-3]. Of particular significance is the use of NHCs in second- and third-generation Grubbs catalysts for their application in olefin metathesis and ring-opening metathesis polymerization [4-7]. Despite the coordination chemistry and rich reactivity of NHCs complexes involving d-block and actinide elements, NHC-ligated rare earth $(\mathrm{Ln}=\mathrm{Sc}, \mathrm{Y}$, $\mathrm{La}, \mathrm{Ce}, \mathrm{Pr}, \mathrm{Nd}, \mathrm{Pm}, \mathrm{Sm}, \mathrm{Eu}, \mathrm{Gd}, \mathrm{Tb}, \mathrm{Dy}, \mathrm{Ho}, \mathrm{Er}, \mathrm{Tm}, \mathrm{Yb}$, and $\mathrm{Lu}$ ) complexes (Ln-NHCs) remain under-developed [8-10]; this could be due partly to the thought of a hard-soft mismatch between the hard Ln(III) center and the soft carbon-donor ligand, and therefore the possible ease of NHCs dissociation during catalysis. Nonetheless, owing to their strong $\sigma$-donating ability, NHCs were shown to be able to form thermally and chemically stable complexes with Ln, and to confer good catalytic activity to the Ln centers [11-15]. 
The development of Ln catalysts for polymerization has attracted a considerable amount of attention in recent decades [16,17]. Compared with transition metal catalysts, Ln complexes are considered to have unique advantages in the coordination polymerization of styrene, the coordination polymerization of conjugated dienes, the ring-opening polymerization of cyclic esters [18-26], and the coordination polymerization of polar monomers [27-34]. Yet, the employment of Ln-NHCs in this area remains relatively unexplored. Given the success of both NHCs and Ln in polymerization chemistry, it is envisioned that NHC-ligated Ln complexes will become a promising class of catalysts in the area of polymerization. With the strong $\sigma$-donating ability and great structural and electronic varieties of NHCs, robust Ln-NHC catalysts with a diverse range of activities can be obtained by a judicious choice of central metals and NHCs. By using hetero-atom-tethered chelating NHCs and other structurally related NHCs, NHC-ligated Ln complexes have been demonstrated to be a fruitful candidate in polymerization. In this review, we describe the recent development of Ln complexes bearing NHCs ligands, covering their synthesis and reactivity, with an emphasis on their applications in polymerization [35]. For a comprehensive overview on the coordination chemistry and reactivity of Ln-NHCs, we refer the reader to a recent book chapter given by Kühn and coworkers [36].

\section{Rare Earth Catalysts Containing a Monodentate NHC Ligand}

In 1994, Schumann et al. synthesized the first NHC-ligated Ln complexes $\left(\mathrm{C}_{5} \mathrm{Me}_{4} \mathrm{Et}\right)_{2} \mathrm{Ln}(\mathrm{NHC})$ $(\mathrm{Ln}=\mathrm{Yb}(\mathbf{1}), \mathrm{Sm}(\mathbf{2}))$ by reacting $\left(\mathrm{C}_{5} \mathrm{Me}_{4} \mathrm{Et}\right)_{2} \mathrm{Ln}(\mathrm{THF})$ with an in situ-generated NHC (Figure 1) $[37,38]$. Subsequently, Arduengo et al. reported the syntheses and molecular structures of the carbene-Sm(II) complex $\left(\mathrm{C}_{5} \mathrm{Me}_{5}\right)_{2} \mathrm{Sm}(\mathrm{NHC})(3)$ and its bis(carbene) adduct $\left(\mathrm{C}_{5} \mathrm{Me}_{5}\right)_{2} \mathrm{Sm}(\mathrm{NHC})_{2}(4)$, and also the mono-carbene $\mathrm{Eu}(5)$ and $\mathrm{Y}(6)$ complexes bearing acetylacetonate ligands (Figure 1) [39]. Owing to its strong nucleophilicity, substitution of a weakly coordinated ligand by NHC remains one of the most common methods for preparing Ln-NHC complexes [40,41].

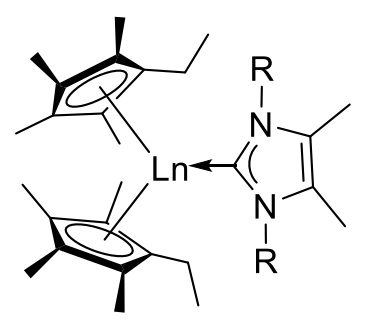

$\mathrm{R}=\mathrm{Me},{ }^{i} \mathrm{Pr}$

$\operatorname{Ln}=\mathrm{Yb}(1) ; \mathrm{Sm}(2)$.

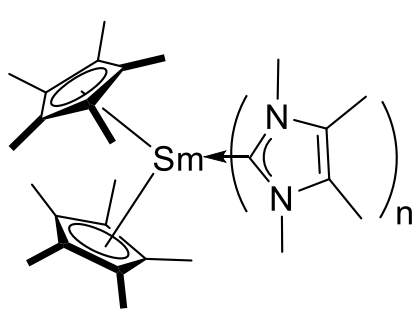

$n=1(3) ; n=2(4)$.

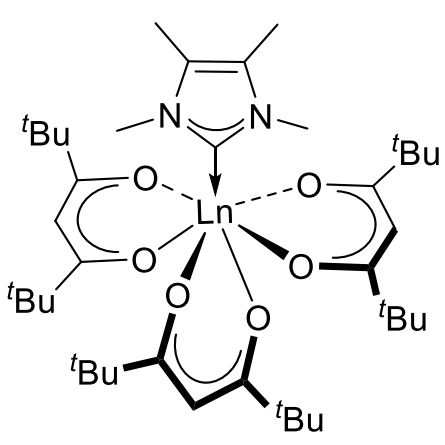

$\operatorname{Ln}=\operatorname{Eu}(5) ; Y(6)$.

Figure 1. Ln complexes with N-heterocyclic carbene (NHC) ligands.

Reactions of $\mathrm{Ln}\left(\mathrm{CH}_{2} \mathrm{SiMe}_{3}\right)_{3}(\mathrm{THF})_{2}(\mathrm{Ln}=\mathrm{Y}, \mathrm{Lu})$ with an in situ-generated bulky NHC, 1,3-bis(2,6-diisopropylphenyl)imidazol-2-ylidene (IPr), afforded the corresponding four coordinated (IPr) $\mathrm{Ln}$ complexes (IPr) $\mathrm{Ln}\left(\mathrm{CH}_{2} \mathrm{SiMe}_{3}\right)_{3}(\mathrm{Ln}=\mathrm{Y}(7), \mathrm{Lu}(8))$ (Figure 2) [42]. The treatment of 1,3-bis(2,4,6-trimethylphenyl)imidazol-2-ylidene (IMes) with $\mathrm{Lu}\left(\mathrm{CH}_{2} \mathrm{SiMe}_{3}\right)_{3}(\mathrm{THF})_{2}$ yielded the expected (IMes) $\mathrm{Lu}\left(\mathrm{CH}_{2} \mathrm{SiMe}_{3}\right)_{3}$ complex (9). However, an attempted synthesis of an yttrium analogue with $\mathrm{Y}\left(\mathrm{CH}_{2} \mathrm{SiMe}_{3}\right)_{3}(\mathrm{THF})_{2}$ led to the formation of a cyclometalated product [(IMes') $)\left(\mathrm{CH}_{2} \mathrm{SiMe}_{3}\right)_{2}(\mathrm{THF})_{2}$ ] (IMes' = IMes deprotonated at the ortho-methyl group of the mesityl substituent) (10), presumably via $\sigma$-bond metathesis. Prolonged reaction of $\mathrm{Lu}\left(\mathrm{CH}_{2} \mathrm{SiMe}_{3}\right)_{3}(\mathrm{THF})_{2}$ with IMes also afforded the corresponding Lu cyclometalated product 11 [42,43]. Not surprisingly, the reactions of $\mathrm{Ln}\left(\mathrm{CH}_{2} \mathrm{SiMe}_{3}\right)_{3}(\mathrm{THF})_{2}(\mathrm{Ln}=\mathrm{Y}, \mathrm{Lu})$ with excess IMes gave rise to the bis-cyclometalated complexes [(IMes' $\left.)_{2} \mathrm{Ln}\left(\mathrm{CH}_{2} \mathrm{SiMe}_{3}\right)\right](\mathrm{Ln}=\mathrm{Y}(\mathbf{1 2}), \mathrm{Lu}(\mathbf{1 3}))$ [43]. 


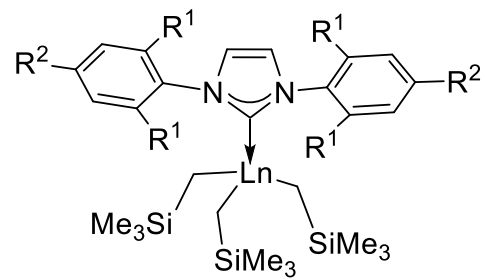

$\mathrm{R}^{1}={ }^{i} \mathrm{Pr}, \mathrm{R}^{2}=\mathrm{H}, \operatorname{Ln}=\mathrm{Y}(\mathbf{7}), \operatorname{Lu}(\mathbf{8})$; $R^{1}=R^{2}=M e, \operatorname{Ln}=\operatorname{Lu}(\mathbf{9})$.

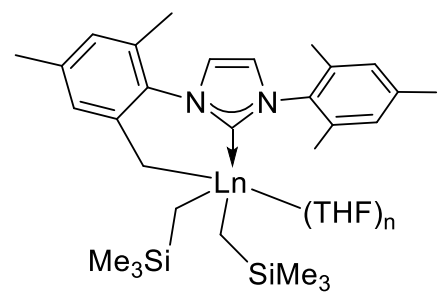

$\operatorname{Ln}=\mathrm{Y}(\mathbf{1 0}), \mathrm{n}=2$ Lu (11), $\mathrm{n}=1$.

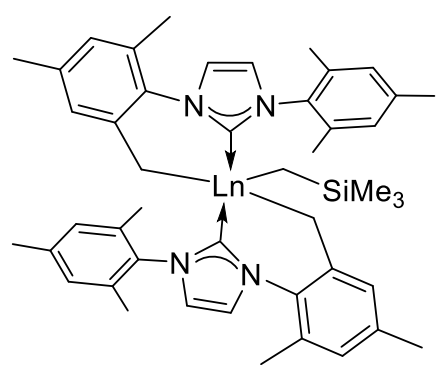

$\operatorname{Ln}=\mathrm{Y}(12) ; \mathrm{Lu}(13)$.

Figure 2. Tri-, dialkyl, or monoalkyl Ln complexes with sterically hindered NHC ligands.

Soon after, the analogous NHC-ligated Sc trialkyl complexes (14 and 15) were also reported by $\mathrm{Lu}$ and co-workers (Figure 3) [44]. The NHC-Sc complexes were found to be active catalysts for $\alpha$-olefin polymerization with very high activities (up to $2520 \mathrm{~kg} \cdot \mathrm{mol}_{\mathrm{sc}^{-1}}{ }^{-1} \mathrm{~h}^{-1}$ ) upon activation with two equivalents of $\left[\mathrm{Ph}_{3} \mathrm{C}\right]\left[\mathrm{B}\left(\mathrm{C}_{6} \mathrm{~F}_{5}\right)_{4}\right]$. The polyolefin with high molecular weight (up to $63.1 \times 10^{4}$ ) could be produced at a low reaction temperature of $30^{\circ} \mathrm{C}$. In comparison, the analogous $\mathrm{Y}$ and Lu complexes showed very low activity or were inert for $\alpha$-olefin polymerization, indicating the metal's dependence on the catalytic activity. Furthermore, the $14 /\left[\mathrm{Ph}_{3} \mathrm{C}\right]\left[\mathrm{B}\left(\mathrm{C}_{6} \mathrm{~F}_{5}\right)_{4}\right]$ system was also efficient in catalyzing the copolymerization of 1-hexene with 1,5-hexadiene to give random copolymers (poly(hexene-co-hexadiene)s) with a wide range of 1,5-hexadiene contents (26.6-98.6 mol\%) (Figure 3). It is noteworthy that the starting material $\mathrm{Sc}\left(\mathrm{CH}_{2} \mathrm{SiMe}_{3}\right)_{3}(\mathrm{THF})_{2}$ showed poor polymerization controllability for $\alpha$-olefin polymerization under the same conditions. This work nicely demonstrates the non-innocence of a monodentate NHC in Ln-catalyzed polymerization.

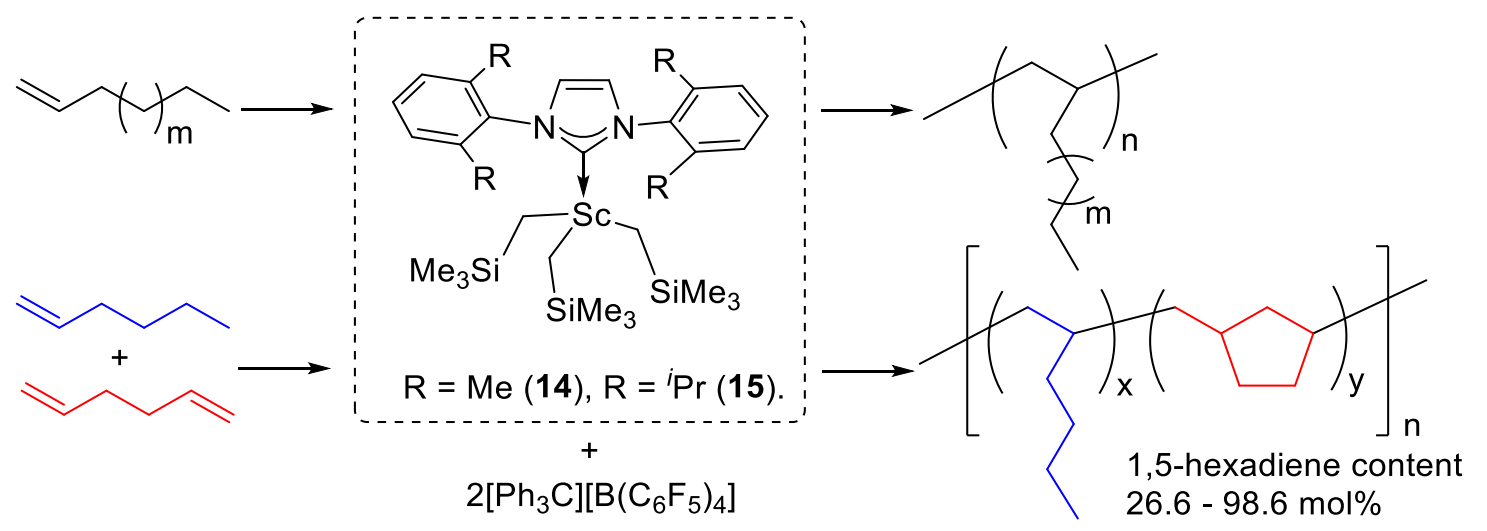

Figure 3. Trialkyl Sc complexes bearing an NHC used for $\alpha$-olefin (co-)polymerization.

Inspired by the successful employment of monodentate NHC ligands in the Ln-catalyzed polymerization reaction, Pan et al. prepared a series of bis(oxazoline)-derived N-heterocyclic carbene (IBiox)-supported Ln trialkyl complexes (IBiox) $\mathrm{Ln}\left(\mathrm{CH}_{2} \mathrm{SiMe}_{3}\right)_{3}(\mathrm{THF})_{\mathrm{n}}(\mathrm{Ln}=\mathrm{Sc}(\mathbf{1 6}), \mathrm{n}=0 ; \mathrm{Y}(\mathbf{1 7}), \mathrm{n}=1$; $\mathrm{Lu}(\mathbf{1 8}), \mathrm{n}=1)$ by the treatment of $\mathrm{Ln}\left(\mathrm{CH}_{2} \mathrm{SiMe}_{3}\right)_{3}(\mathrm{THF})_{2}$ with one equivalent of the freshly prepared IBiox (Figure 4) [45]. A single crystal X-ray diffraction study revealed that the geometry around the metal center in $\mathbf{1 6}$ is pseudo tetrahedral, while those of $\mathbf{1 7}$ and $\mathbf{1 8}$ are distorted trigonal bipyramidal with a coordinated tetrahydrofuran (THF). Upon activation with two equivalents of $\left[\mathrm{Ph}_{3} \mathrm{C}\right]\left[\mathrm{B}\left(\mathrm{C}_{6} \mathrm{~F}_{5}\right)_{4}\right]$, 16 exhibited high activity for the polymerization of 1-hexene (up to $285 \mathrm{~kg} \cdot \mathrm{mol}_{\mathrm{sc}}{ }^{-1} \cdot \mathrm{h}^{-1}$ ) with the resultant polymers dominated by vinylene end groups ( $c$. 95\%). On the other hand, the analogous $\mathrm{Y}$ and $\mathrm{Lu}$ complexes were inactive for the polymerization. The copolymerization of 1-hexene with 1,7-octadiene could also be achieved by using the catalytic system of $16 /\left[\mathrm{Ph}_{3} \mathrm{C}\right]\left[\mathrm{B}\left(\mathrm{C}_{6} \mathrm{~F}_{5}\right)_{4}\right]$ to generate random poly(hexene-co-octadiene). Incomplete cyclization of 1,7 -octadiene resulted in about $20 \%$ 
pendant vinyl groups in the copolymers. The hydrophilicity of the resulting copolymers could be enhanced by functionalizing the vinyl groups into the carboxylic acid groups via a thiol-ene reaction.
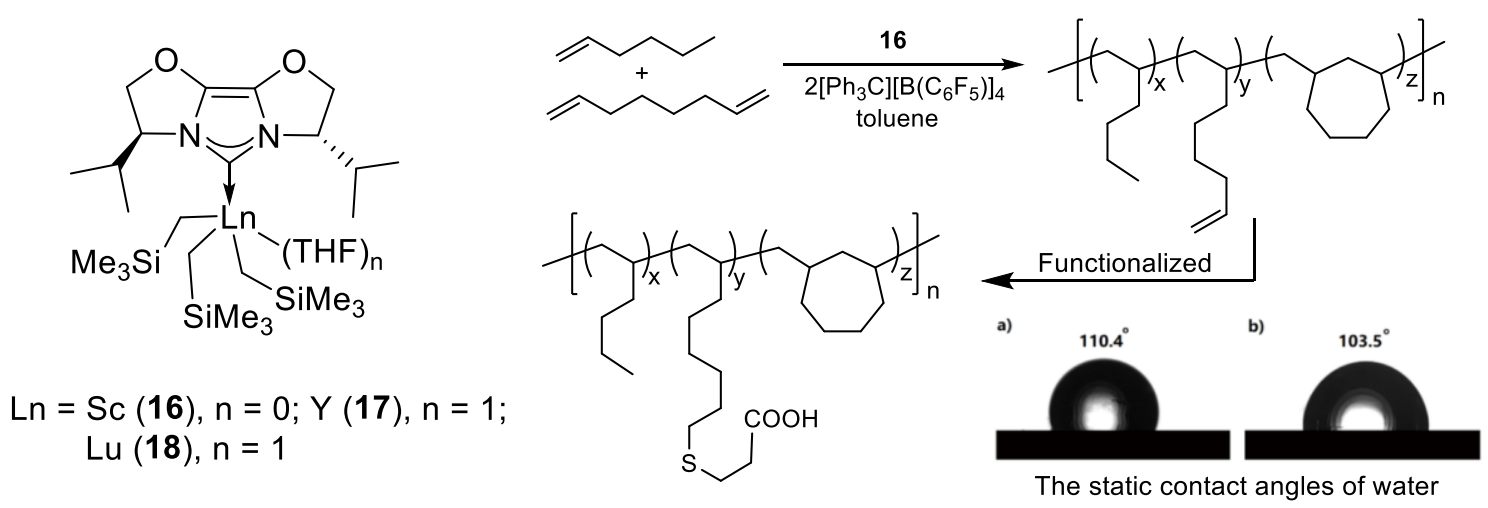

Figure 4. The trialkyl Sc complex bearing a bis(oxazoline)-derived NHC (IBiox) used for copolymerization of olefins.

The monodentate NHC-supported $\mathrm{Yb}(\mathrm{II})$ amido complexes [ $\left.(\mathrm{NHC}) \mathrm{Yb}\left\{\mathrm{N}\left(\mathrm{SiMe}_{3}\right)_{2}\right\}_{2}\right](\mathrm{NHC}=1,3-$ diisopropyl-4,5-dimethyl-imidazol-2-ylidene $\left({ }^{i} \operatorname{Pr}\right)(19)$, 1,3-bis(2,4,6-trimethylphenyl)-imidazol-2-ylidene (IMes) (20)) were prepared by the reactions of THF-coordinated $\mathrm{Yb}$ amides with one equivalent of the NHC ligand (Figure 5) [46]. The NHC-Yb amido complexes were effective catalysts for the dehydrogenative cross-coupling reactions of secondary amines (e.g., $\mathrm{HN}\left(\mathrm{SiMe}_{3}\right)_{2}, \mathrm{HN}^{i} \mathrm{Pr}_{2}$, and $\mathrm{HNEt}_{2}$ ) with $\mathrm{PhSiH}_{3}$ to give various coupling products. The use of bulky 20 allowed for the selective formation of a single coupling product by changing the molar ratios of the two substrates. Followed by this work, the bis-NHC-Yb(II) amides $(\mathrm{NHC})_{2} \mathrm{Yb}\left[\mathrm{N}\left(\mathrm{SiMe}_{3}\right)_{2}\right]_{2}(\mathrm{NHC}=$ 1,3,4,5-tetramethylimidazo-2-ylidene ( $\left.\left.\mathrm{IMe}_{4}\right)(21), I^{i} \operatorname{Pr}(22)\right)$ and the NHC-stabilized $\mathrm{Yb}$ (II) phosphide $\left(\mathrm{IMe}_{4}\right)_{3} \mathrm{Yb}\left(\mathrm{PPh}_{2}\right)_{2}(\mathbf{2 3})$ were synthesized by Cui and coworkers (Figure 5) [47]. Complexes 21-23 were active precatalysts in the hydrophosphination of alkenes, alkynes, and dienes and were superior to the NHC-free amido complex (THF $)_{2} \mathrm{Yb}\left[\mathrm{N}(\mathrm{SiMe})_{2}\right]_{2}$. This suggested the importance of an NHC ligand in boosting this catalysis. Furthermore, it was found that complex 23 could catalyze the polymerization of styrene to yield atactic polystyrenes with low molecular weights $\left(M_{n}=0.85-18.2 \times 10^{4}\right)$. Intermolecular Lewis pair complexes based on homoleptic Ln aryloxides, $\operatorname{Ln}(\mathrm{OAr})_{3}(\mathrm{Ln}=\mathrm{La}, \mathrm{Sm}, \mathrm{Y})$, and NHCs were observed to activate dihydrogen under mild conditions [48]. In addition, the $\mathrm{La}(\mathrm{OAr})_{3} / \mathrm{NHC}$ pair also exhibited frustrated Lewis pair (FLP)-like reactivity towards carbon dioxide and phenylacetylene (Figure 6).<smiles></smiles>

$\mathrm{R}={ }^{i} \operatorname{Pr}(19) ;$ mesityl (20).<smiles></smiles>

$\mathrm{R}=\mathrm{Me}(\mathbf{2 1}) ;{ }^{i} \operatorname{Pr}(\mathbf{2 2})$.

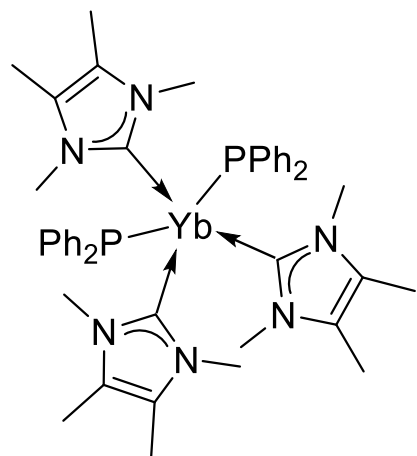

23

Figure 5. NHC-ligated Ln amides and phosphide used as catalysts for organic synthesis. 


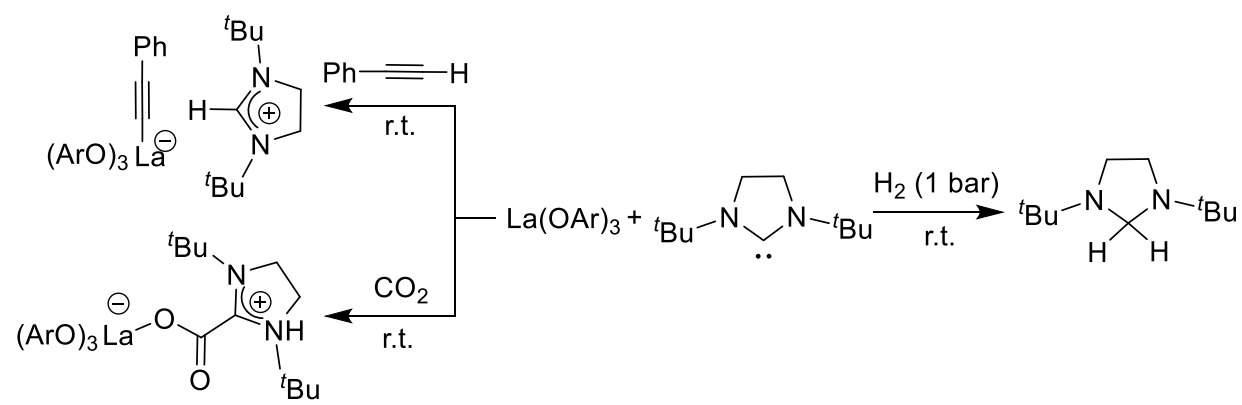

Figure 6. NHC-ligated Ln amides and phosphide used as catalysts for organic synthesis.

To enrich our understanding of bonding between an NHC ligand and Ln metals, the search for structurally related NHCs and the study of their structural and electronic properties have also drawn a considerable amount of attention [49-51]. In this regard, Liddle and coworkers reported a general route to prepare f-element complexes containing a neutral mesoionic carbene (MIC) [52].

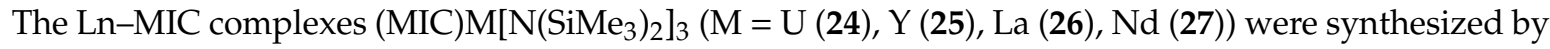
the reaction of $\mathrm{Ln}\left[\mathrm{N}\left(\mathrm{SiMe}_{3}\right)_{2}\right]_{3}$ with an MIC via a formal 1,4-proton migration (Figure 7). Computational studies showed that the $\mathrm{Ln}-\mathrm{C}(\mathrm{MIC})$ bond is mostly composed of MIC $\rightarrow \mathrm{Ln} \sigma$ donation, in contrast to the analogous actinide (An)-MIC complexes that exhibit both MIC $\rightarrow$ An $\sigma$ donation and An $\rightarrow$ MIC $\pi$ back-bonding.
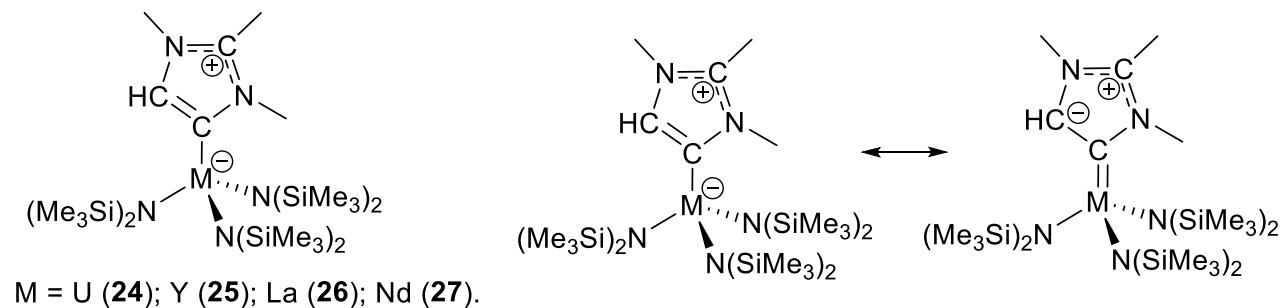

Figure 7. U and Ln-mesoionic carbene (MIC) complexes and two of the principal resonance forms for the MIC complexes.

\section{Rare Earth Catalysts Containing a Heteroatom-Tethered NHC Ligand}

Since the monodentate NHC ligand was thought to be labile in Ln-catalyzed reactions, much effort has been devoted to the development of chelating an NHC ligand with a heteroatom sidearm to facilitate complexation. Arnold et al. has pioneered the employment of an anionic heteroatom-tethered NHC to support Ln complexes [53]. The amido- and alkoxo-tethered NHC-supported Ln complexes were developed, some of which can induce addition-elimination reactions to activate small molecules and forge C-C and C-Si bonds [54-59]. The Y (28) and Ti (29) complexes with heteroatom-tethered NHCs are bifunctional catalysts for the ring-opening polymerization (ROP) of lactide, by using a combination of Lewis acid and base functionalities to initiate the ring-opening of the cyclic monomer (Figure 8) [54].

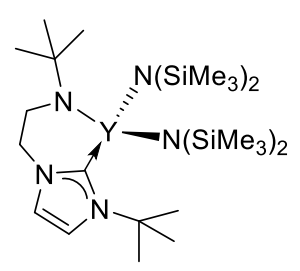

28

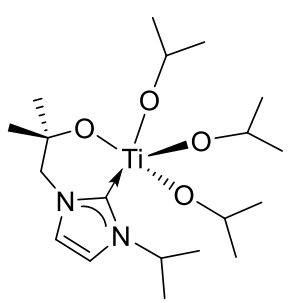

29

Figure 8. The $\mathrm{Y}$ and Ti complexes bearing heteroatom-tethered NHC ligands used for ring-opening polymerization (ROP) of lactide. 
Furthermore, Arnold and coworkers have synthesized a homolytic Sc complex containing three equiv. of alkoxo-tethered NHCs (Alko-NHC), Sc(Alko-NHC) $)_{3}(30)$, via the treatment of $\mathrm{ScCl}_{3}(\mathrm{THF})_{3}$ with the potassium salt of Alko-NHC (Figure 9) [60]. Complex 30 exhibited frustrated-Lewis-pair type behavior that could activate three equivalents of $\mathrm{CO}_{2}$ via the $\mathrm{Sc}-\mathrm{C}(\mathrm{NHC})$ bond. On the other hand, activation of $\mathrm{CS}_{2}$ by 30 solely involved the NHC moiety. Another class of homoleptic Ln-tris(aryloxotethered NHC) complexes, $\mathrm{Ln}\left(\right.$ Arylo-NHC) ${ }_{3}(\mathrm{Ln}=\mathrm{Ce}, \mathrm{Sm}$, and $\mathrm{Eu})(31-35)$, were also synthesized by treatment of the corresponding ortho-aryloxide imidazolium salt proligand with $\mathrm{KN}\left(\mathrm{SiMe}_{3}\right)_{2}$ followed by salt metathesis with $\mathrm{LnCl}_{3}(\mathrm{THF})_{\mathrm{n}}$ (Figure 9) [61]. The Ce complexes 31 and 34 were capable of activating $\mathrm{CO}_{2}$ and its isoelectronic heteroallenes using the $\mathrm{Ce}-\mathrm{C}(\mathrm{NHC})$ bonds. It should be noted that the insertion of $\mathrm{CO}_{2}$ into the mesityl-substituted complex 35 is reversible. This led to the catalytic formation of propylene carbonate in the presence of propylene oxide under $1 \mathrm{~atm}$ of $\mathrm{CO}_{2}$ (Figure 10).

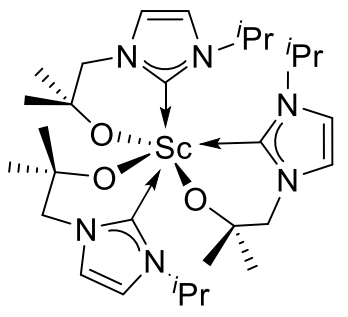

30

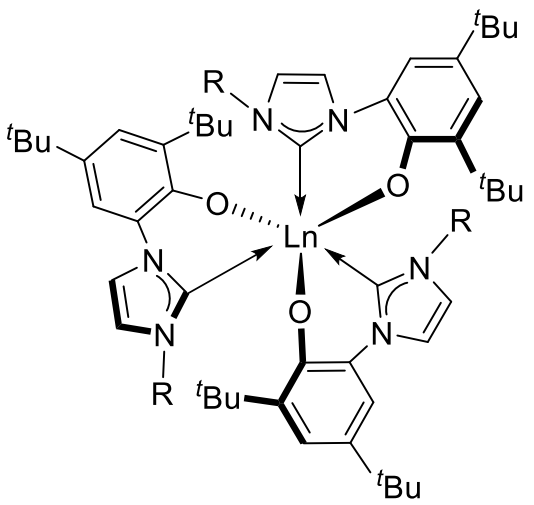

$\mathrm{R}={ }^{i} \mathrm{Pr}: \operatorname{Ln}=\mathrm{Ce}(31) ; \mathrm{Sm}(32) ; \mathrm{Eu}(33) ;$

$\mathrm{R}={ }^{t} \mathrm{Bu}: \mathrm{Ln}=\mathrm{Ce}(\mathbf{3 4})$;

$\mathrm{R}=$ Mes $: \operatorname{Ln}=\mathrm{Ce}(\mathbf{3 5})$.

Figure 9. Homoleptic Ln complexes with alkoxo/aryloxo-tethered NHC ligands.

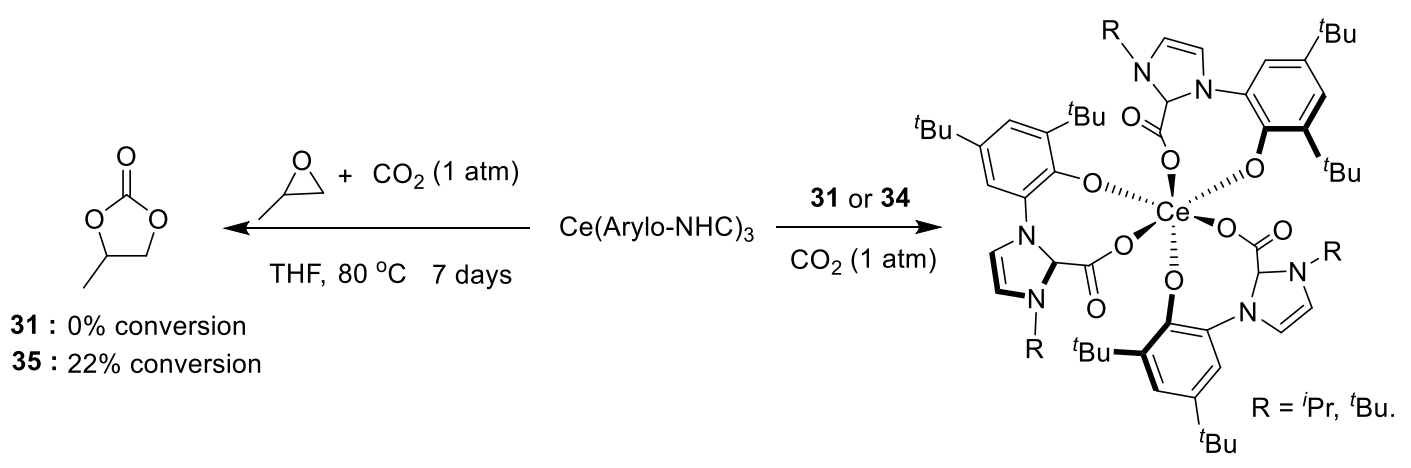

Figure 10. Reactivity of $\mathrm{Ce}(\text { Arylo-NHC })_{3}$ with $\mathrm{CO}_{2}$ and their catalytic performance on the formation of propylene carbonate [59].

Shen and coworkers have also contributed to the synthesis and development of catalytic reactions with aryloxo-tethered NHC-supported Ln complexes [62-64]. Treatment of $\operatorname{Li}\left[\operatorname{Ln}\left(\mathrm{N}^{i} \operatorname{Pr}_{2}\right)\right]_{4}(\operatorname{Ln}=\mathrm{Yb}, \mathrm{Y})$ with aryloxo-tethered $\mathrm{NHC}$ precursors and ${ }^{n} \mathrm{BuLi}$ at a low temperature afforded the amido $\mathrm{Yb}$ complexes 36 and 37, or homoleptic $Y$ complex 38. When the reaction of $\operatorname{Li}\left[Y\left(\mathrm{~N}^{i} \mathrm{Pr}_{2}\right)\right]_{4}$ with an aryloxo-tethered NHC precursor and ${ }^{n} \mathrm{BuLi}$ was carried out at room temperature, the $\mathrm{Y}$ complex 39 supported by a bridging bisphenoxo group was obtained, presumably derived from the cleavage of the NHC ligand (Figure 11) [63]. Cationic amido-phenoxo-functionalized NHC-ligated Ln bromides ( $\mathrm{Ln}=\mathrm{Y}(40)$, Lu (41), $\mathrm{Er}(42))$ were obtained from the transmetalation reaction of $\mathrm{LnCl}_{3}$ with $\mathrm{NHC}$-ligated $\mathrm{Li}$ in a molar ratio of 1:1 at room temperature, which could also be in situ formed by the salicylaldimino-functionalized imidazolium bromide with ${ }^{n} \mathrm{BuLi}$ (Figure 11) [64]. 


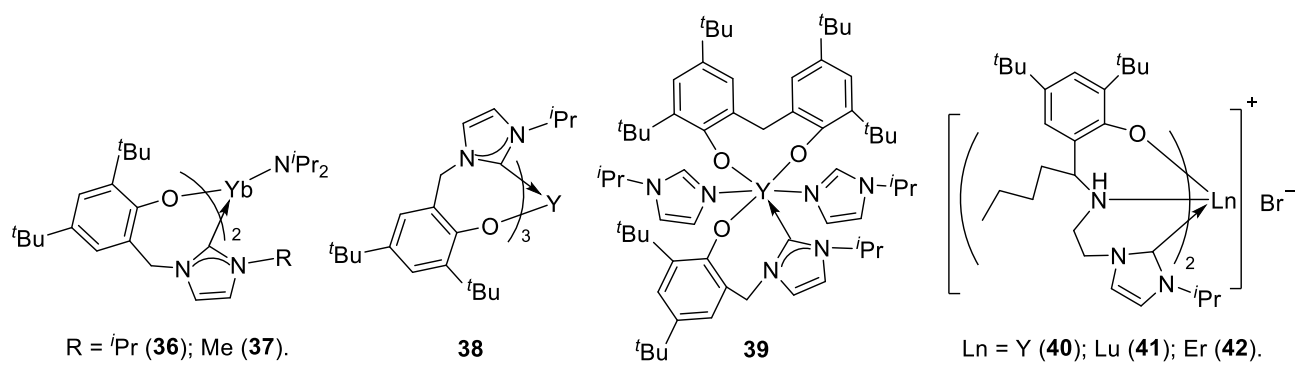

Figure 11. Ln complexes bearing alkoxy-NHC ligands.

Treatment of $\mathrm{Ln}\left(\mathrm{CH}_{2} \mathrm{SiMe}_{3}\right)_{3}(\mathrm{THF})_{2}$ with freshly prepared fluorenyl-tethered NHC proligand led to the formation of fluorenyl-NHC (Flu-NHC)-ligated Ln dialkyl complexes (Flu-NHC) $\mathrm{Ln}\left(\mathrm{CH}_{2} \mathrm{SiMe}_{3}\right)_{2}$ $(\mathrm{Ln}=\mathrm{Sc}(43), \mathrm{Y}(44), \mathrm{Lu}(45), \mathrm{Ho}(46), \mathrm{Dy}(47), \mathrm{Er}(48))$, along with the elimination of $\mathrm{SiMe}_{4}$ and THF (Figure 12) $[65,66]$. Upon activation with $\mathrm{Al}^{i} \mathrm{Bu}_{3}$ and $\left[\mathrm{Ph}_{3} \mathrm{C}\right]\left[\mathrm{B}\left(\mathrm{C}_{6} \mathrm{~F}_{5}\right)_{4}\right]$, complexes 44-46 exhibited livingness in the polymerization of isoprene at various monomer-to-catalyst ratios under a broad range of temperatures (from $25^{\circ} \mathrm{C}$ to $80^{\circ} \mathrm{C}$ ) [66]. The resultant polyisoprenes (PIPs) are of high 3,4-regioselectivity (up to $99 \%$ ) and medium syndiotacticity, resulting in a kind of crystalline polymer. The catalytic activity and specific selectivity are strongly dependent on the steric hindrance of the ancillary ligand and central metal. Complexes 44,45 , and 46 bearing a fluorenyl moiety exhibited higher 3,4-regioselectivity than complexes $\mathbf{5 0}, \mathbf{5 1}$, and $\mathbf{5 2}$ bearing an indenyl moiety with the same central metal. The Sc complexes 43 and 49 were inert for the isoprene polymerization.
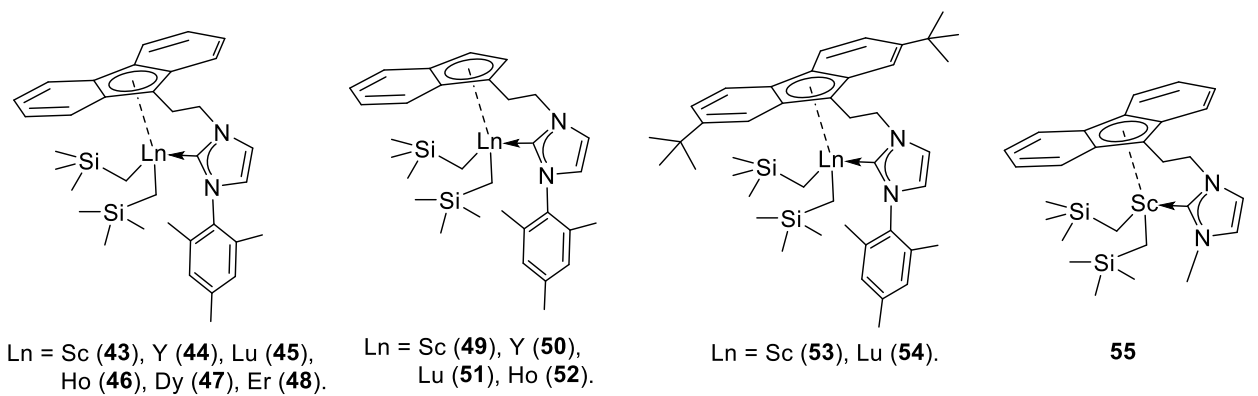

Ho (46), Dy (47), Er (48)

Lu (51), Ho (52).

Figure 12. NHC side-armed half-sandwich Ln complexes.

On the other hand, half-sandwich Sc complexes bearing a CGC-type NHC (43, 49, and 53) exhibited medium to high catalytic activity in the polymerization of ethylene, while the $\mathrm{Y}$ and $\mathrm{Lu}$ analogues were inactive. In addition, the copolymerization of ethylene with norbornene, 1-hexene, or 1-octene could be achieved with high activity ( $\mathrm{ca} .3600-5000 \mathrm{~kg} \cdot \mathrm{mol}_{\mathrm{Sc}}{ }^{-1} \cdot \mathrm{h}^{-1} \cdot \mathrm{atm}^{-1}$ ) by using the $43 / \mathrm{Al}^{i} \mathrm{Bu}_{3} /\left[\mathrm{Ph}_{3} \mathrm{C}\right]\left[\mathrm{B}\left(\mathrm{C}_{6} \mathrm{~F}_{5}\right)_{4}\right]$ catalytic system (Figure 13) $[67,68]$. The thermal properties of the copolymers could be conveniently adjusted by changing the feed ratio of ethylene and co-monomer. The copolymerization of ethylene and styrene or other styrene derivatives could be successfully achieved by the $43 / \mathrm{Al}^{i} \mathrm{Bu}_{3} /\left[\mathrm{Ph}_{3} \mathrm{C}\right]\left[\mathrm{B}\left(\mathrm{C}_{6} \mathrm{~F}_{5}\right)_{4}\right]$ system to produce a series of pseudo-random copolymers. The incorporation content of the styrene monomer could be tuned swiftly from $16.1 \mathrm{~mol} \%$ to $43.2 \mathrm{~mol} \%$ through varying the monomer's feeding mole ratio and polymerization time, and no consecutive styrene sequences were observed in the copolymers [69]. According to the NMR spectra of the copolymers, there were no consecutive styrene sequences and the copolymers showed only one glass transition temperature, which could vary from $-21.2{ }^{\circ} \mathrm{C}$ to $18.2{ }^{\circ} \mathrm{C}$ by changing the styrene content. Remarkably, the direct copolymerization of ethylene with a series of unmasked polar styrenes and nonpolar styrenes could be achieved by using an NHC side-armed fluorenyl Sc complex. Complex 55 with a methyl-substituted NHC showed the highest activity $\left(319 \mathrm{~kg} \cdot \mathrm{mol}_{\mathrm{Sc}}{ }^{-1} \cdot \mathrm{h}^{-1} \cdot \mathrm{atm}^{-1}\right)$, which was 10 times higher than the sterically bulky complex 43 [70]. All the resultant copolymers are composed 
of pseudo-alternating microstructures. The copolymer with a perfect alternating structure could be generated when para-( $\mathrm{N}, \mathrm{N}$-dimethylamino)styrene was used as a co-monomer.

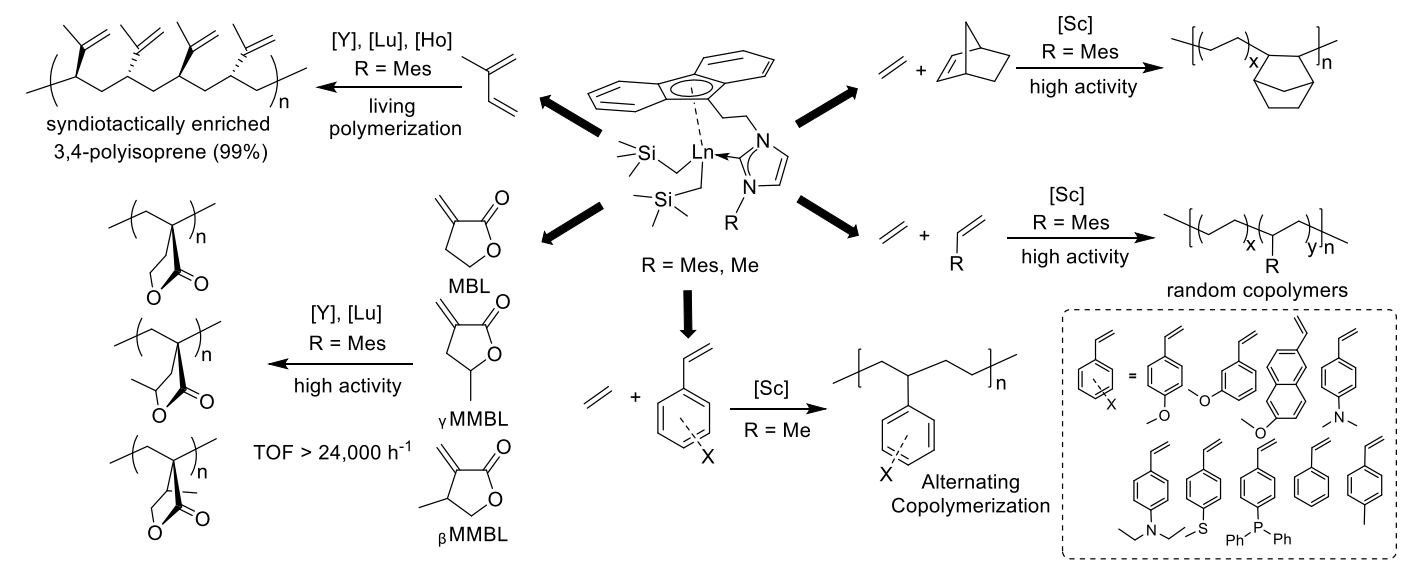

Figure 13. NHC side-armed half-sandwich Ln complexes used for coordination polymerization.

In addition to the coordination polymerization, the $\mathrm{Y}$ and $\mathrm{Lu}$ complexes (Flu-NHC) $\mathrm{Ln}\left(\mathrm{CH}_{2} \mathrm{SiMe}_{3}\right)_{2}$ $(\mathrm{Ln}=\mathrm{Y}(44), \mathrm{Lu}(45))$ were also employed as the catalysts for rapid and stereoselective polymerization of renewable methylene methylbutyrolactones, such as $\alpha$-methylene- $\gamma$-butyrolactone (MBL), $\gamma$-methyl- $\alpha$-methylene- $\gamma$-butyrolactone ( $\gamma \mathrm{MMBL})$, and $\beta$-methyl- $\alpha$-methylene- $\gamma$-butyrolactone $\left({ }_{\beta}\right.$ MMBL) (Figure 13) [71]. Both 44 and 45 were highly active for the polymerization of ${ }_{\gamma}$ MMBL at room temperature, achieving an exceptionally high turnover frequency (TOF) of $24,000 \mathrm{~h}^{-1}$, which was 2400 times higher than that of homoleptic Ln-trialkyls. Moreover, 44 and $\mathbf{4 5}$ were also found to be active in the homopolymerization of ${ }_{\beta}$ MMBL and its copolymerization with $\gamma$ MMBL, which represents the first example of metal-catalyzed coordination polymerization of ${ }_{\beta}$ MMBL. The homopolymer resulting from ${ }_{\beta}$ MMBL displays high stereoregularity $(91 \% \mathrm{~mm})$ with a high $T_{\mathrm{g}}$ of $290^{\circ} \mathrm{C}$.

Admidinate-tethered NHCs (Amidino-NHC) were also employed by Cui et al. for the synthesis of amidino-NHC-supported Ln complexes (56-59) (Figure 14) [72]. Under the activation with $\left[\mathrm{Ph}_{3} \mathrm{C}\right]\left[\mathrm{B}\left(\mathrm{C}_{6} \mathrm{~F}_{5}\right)_{4}\right]$, the Lu complexes (57-59) exhibited high activities and 3,4-selectivities $(96.9 \%)$ in the polymerization of 2-phenyl-1,3-butadiene in a living mode to afford new plastic polydienes with high glass transition temperatures $\left(T_{\mathrm{g}}=44.3-56.1^{\circ} \mathrm{C}\right)$. However, the analogous Sc complex 56 was inert under the same reaction conditions. The different catalytic performance of $\mathbf{5 6}$ and $\mathbf{5 7}$ on isoprene polymerization is similar to that of $\mathbf{4 3}$ and $\mathbf{4 5}$ with a fluorenyl-tethered NHC ligand, showing the importance of the type of central metal.
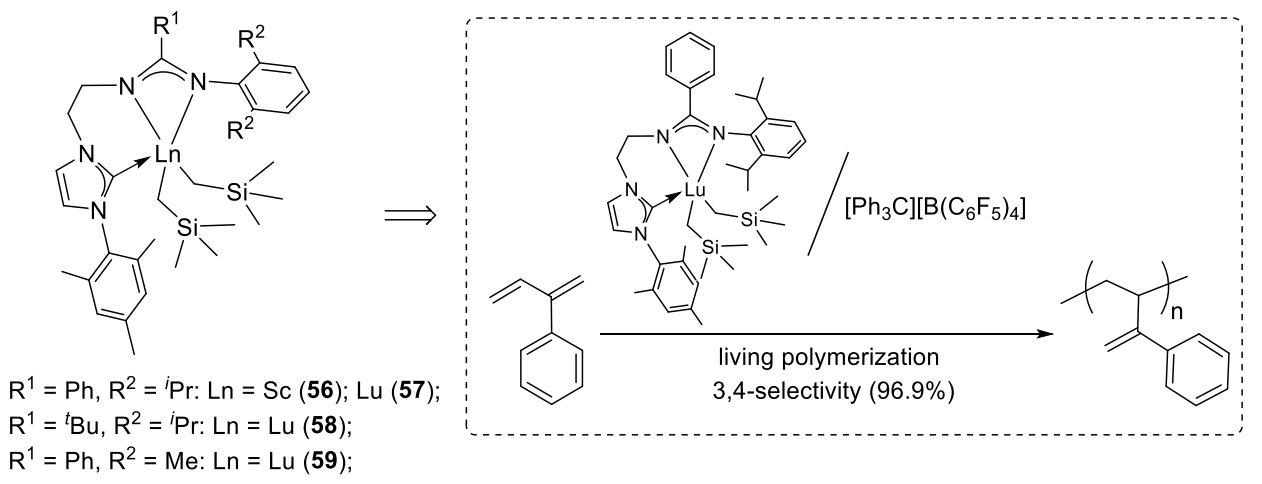

Figure 14. The amidino-NHC ligand-supported Ln complexes used for polymerization of 2-phenyl-1,3-butadiene. 


\section{Rare Earth Catalysts Containing a Tridentate NHC Ligand}

Tridentate ligands, such as pincer-type ligands (pincer phosphines, amines, and NHC ligands), have widely been used to support transition metal catalysts and usually show high thermal stability and well-defined reactivity [73-78]. Therefore, efforts have also been devoted to develop Ln catalysts supported by a tridentate NHC ligand.

A series of CCC-pincer 2,6-xylenyl bis(carbene)-ligated Ln dibromides (60-69) were synthesized via the treatment of imidazolium dibromide proligands and $\mathrm{LnCl}_{3}$ with dropwise addition of ${ }^{n} \mathrm{BuLi}$ (Figure 15) $[79,80]$. The $\mathrm{Y}, \mathrm{Nd}, \mathrm{Gd}$, Dy, and Ho complexes exhibited high activity and cis-1,4 selectivity $\left(99.6 \%, 25^{\circ} \mathrm{C}\right)$ in the polymerization of isoprene under activation with $\mathrm{AlR}_{3}\left(\mathrm{R}=\mathrm{Me}, \mathrm{Et},{ }^{i} \mathrm{Bu}\right)$ and $\left[\mathrm{Ph}_{3} \mathrm{C}\right]\left[\mathrm{B}\left(\mathrm{C}_{6} \mathrm{~F}_{5}\right)_{4}\right]$, while the others were inactive. Moreover, this system maintained a high cis-1,4 selectivity $(97.4 \%)$ at $80^{\circ} \mathrm{C}$, indicating its tolerance to elevated temperature conditions. According to the analysis of in situ NMR spectra, the yttrium hydrido aluminate cation was speculated to be the active species.
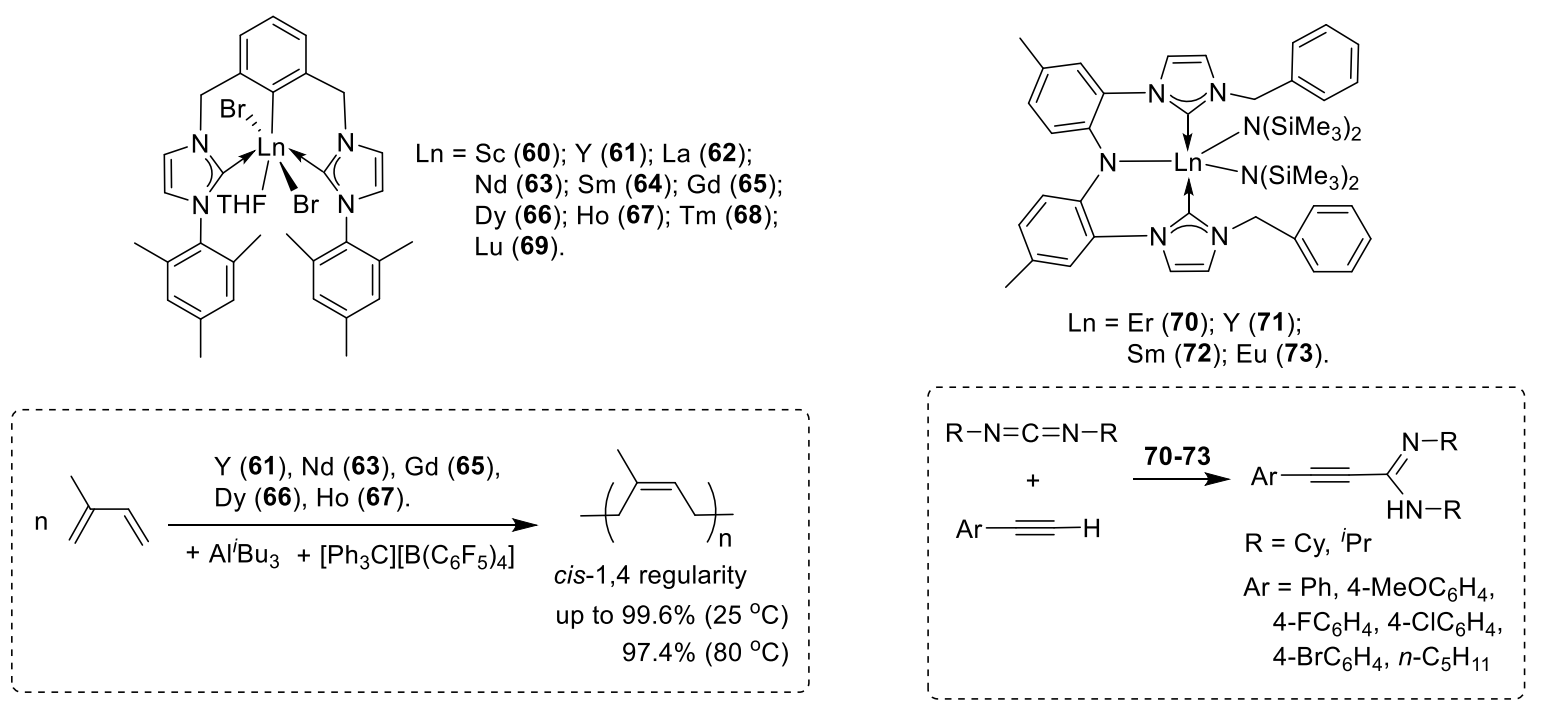

Figure 15. CCC- and CNC-pincer Ln complexes.

Wang and coworkers have reported the synthesis of a number of Ln amides supported by a CNC-pincer ligand (denoted as diarylamido-linked biscarbene (DLB)) (Figure 15) [81,82]. Reaction of the in situ-generated DLB with $\left[\left(\mathrm{Me}_{3} \mathrm{Si}\right)_{2} \mathrm{~N}\right]_{3} \mathrm{Ln}(\mu-\mathrm{Cl}) \mathrm{Li}(\mathrm{THF})_{3}$ afforded the CNC-pincer complexes (DLB) $\operatorname{Ln}\left[\mathrm{N}\left(\mathrm{SiMe}_{3}\right)_{2}\right]_{2}$ ( $\left.\mathrm{Ln}=\mathrm{Er}(70), \mathrm{Y}(71), \mathrm{Sm}(72), \mathrm{Eu}(73)\right)$. Alternatively, complexes 70-73 could also be prepared by one-pot reaction of the DLB proligand $\left(\mathrm{H}_{3} \mathrm{DLB}-\mathrm{Cl}_{2}\right)$ with five equivalents of $\mathrm{NaN}\left(\mathrm{SiMe}_{3}\right)_{2}$, followed by the treatment with $\mathrm{LnCl}_{3}$. These complexes displayed good catalytic activity in the addition of terminal alkynes to carbodiimides to give propiolimidines, which was the first example in Ln chemistry to catalyze such an organic transformation at room temperature (Figure 15).

Shen, $\mathrm{Ni}$, and their coworkers have designed and synthesized two chelating bis(phenolate)-NHC (BisP-NHC) ligands for Ln complexation [83-85]. The BisP-NHC proligands featuring a five-membered (denoted as BisP-NHC-5 hereafter) and a six-membered (denoted as BisP-NHC-6 hereafter) imidazolinium rings were prepared using the corresponding $\mathrm{H}_{2}$ Salen. The treatments of the BisP-NHC-5 proligand with $\mathrm{KN}\left(\mathrm{SiMe}_{3}\right)_{2}$ and $\left[\mathrm{Ln}\left\{\mathrm{N}\left(\mathrm{SiMe}_{3}\right)_{2}\right\}_{3}\right]$ afforded the heterobimetallic $\mathrm{Ln} / \mathrm{K}$ complexes Ln(BisP-NHC-5)K(THF) ( $\mathrm{Ln}=\mathrm{Nd}(74), \mathrm{Sm}$ (75), Y (76), $\mathrm{La}(77)$ ), while that with $\mathrm{KN}\left(\mathrm{SiMe}_{3}\right)_{2}$ and $\left[\left(\mathrm{Me}_{3} \mathrm{Si}\right)_{2} \mathrm{~N}\right]_{3} \mathrm{Nd}(\mu-\mathrm{Cl}) \mathrm{Li}(\mathrm{THF})_{3}$ led to the isolation of a Nd/Li complex Nd(BisP-NHC-5)Li(THF) (78)

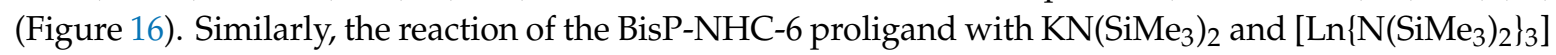
resulted in the formation of heterobimetallic $\mathrm{Ln} / \mathrm{K}$ complexes $\mathrm{Ln}(\mathrm{BisP}-\mathrm{NHC}-6) \mathrm{K}(\mathrm{THF})(\mathrm{Ln}=\mathrm{Nd}(79)$, $\mathrm{Y}(\mathbf{8 0}))$. In the absence of $\mathrm{KN}\left(\mathrm{SiMe}_{3}\right)_{2}$, the reactions of BisP-NHC-5 or BisP-NHC-6 proligands with 
$\left[\mathrm{Ln}\left\{\mathrm{N}\left(\mathrm{SiMe}_{3}\right)_{2}\right\}_{3}\right]$ or $\left[\left(\mathrm{Me}_{3} \mathrm{Si}\right)_{2} \mathrm{~N}\right]_{3} \mathrm{Ln}(\mu-\mathrm{Cl}) \mathrm{Li}(\mathrm{THF})_{3}$ only gave rise to dinculear Ln complexes (81-85) containing bridging chlorides and imidazolinium-bridged bis(phenolate) ligands (Figure 16).

The complexes 74-78 were effective catalysts in the ROP of L-lactide (L-LA) to obtain polylactides with moderate molecular weight $\left(M_{n}=7-21 \times 10^{3}\right)$, while the dinuclear 81-83 were found to be inactive for this polymerization [84]. Similarly, the heterobimetallic $\mathrm{Ln} / \mathrm{K}$ complexes $74-76,79$, and 80 containing an Ln-NHC moiety were highly active in catalyzing the polymerization of $n$-hexyl isocyanate to give polymers with a very high molecular weight (up to $10^{6}$ ) and a narrow molecular weight distribution $\left(M_{\mathrm{w}} / M_{\mathrm{n}}=1.7-2.3\right)$, whereas the dinuclear complexes 81,84 , and 85 were inert for this transformation [85]. These results indicate the importance of an Ln-NHC moiety for initiating the ROP of ${ }_{\mathrm{L}}$-LA and polymerization of $n$-hexyl isocyanate.
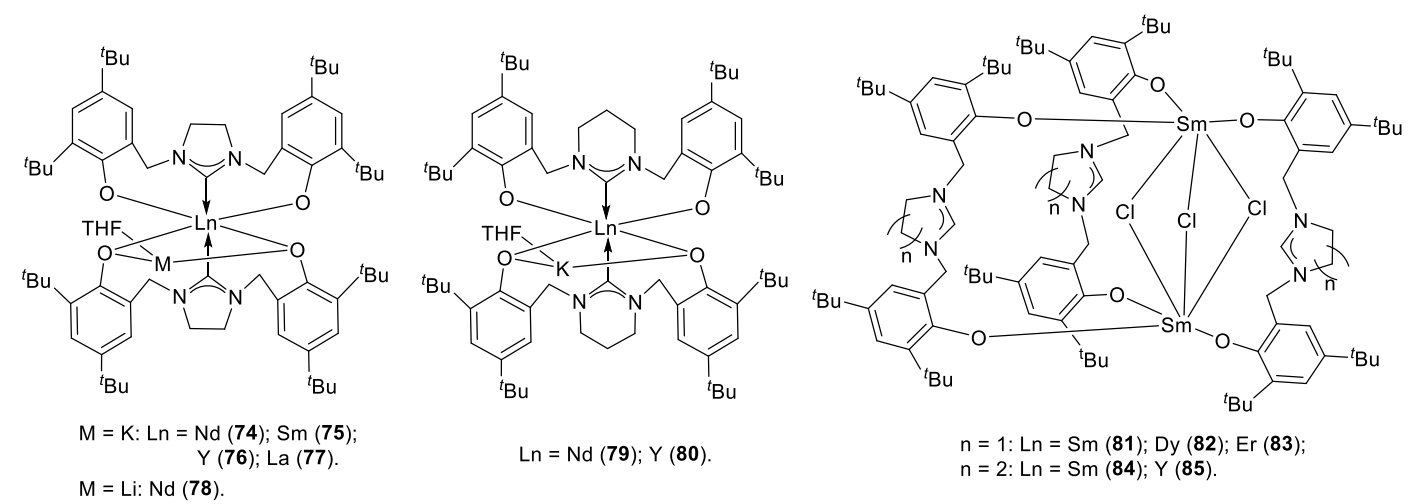

Figure 16. The Ln complexes bearing chelating bis(phenolate)-NHC ligands (BisP-NHC-5 and BisP-NHC-6) [81,82].

Two similar phenol-tethered NHC proligands featuring six-membered imidazolinium rings (PhenoH-NHC-1 and PhenoH-NHC-2) were also prepared by Ni and coworkers. However, unlike the bis(phenolate)-NHC analogue, the reactions of PhenoH-NHC- 1 or PhenoH-NHC-2 with $\mathrm{KN}\left(\mathrm{SiMe}_{3}\right)_{2}$ and $\mathrm{Ln}\left[\mathrm{N}\left(\mathrm{SiMe}_{3}\right)_{2}\right]_{3}$ only led to the isolations of heterobimetallic $\mathrm{Ln} / \mathrm{K}$ complexes containing a bridging Pheno-NHC-1 or Pheno-NHC-2, which binds to the Ln(III) and K(I) centers via oxygen and carbon atoms, respectively [86].

\section{Conclusions}

In summary, considerable efforts have been devoted to the development of Ln complexes containing NHCs. Both monodentate NHCs and heteroatom-tethered NHCs have been shown to be a good supporting ligand for Ln catalysts and their applications in polymerization reactions. Given each previous success of Ln and NHCs in the area of polymerization, one can envision that the development of NHC-ligated Ln catalysts in polymerization chemistry will flourish.

Author Contributions: Conceptualization, Y.P. and Y.-M.S.; writing-original draft preparation, Y.P., X.J., and Y.-M.S.; writing—review and editing, Y.P., Y.-M.S., and C.T.T.; supervision, G.H. All authors have read and agreed to the published version of the manuscript.

Funding: This research was funded by the National Natural Science Foundation of China (21971029) and the State Key Laboratory of Fine Chemicals (KF1711). And the APC was funded by the Fundamental Research Funds for the Central Universities (DUT19LK27) and the Natural Science Foundation of Liaoning Province, China (20180550505).

Acknowledgments: We are grateful to Xiaohui Kang in Dalian Medical University and Gen Luo in Anhui University for their helpful discussion and suggestion.

Conflicts of Interest: The authors declare no conflicts of interest.

\section{References}

1. Hopkinson, M.N.; Richter, C.; Schedler, M.; Glorius, F. An Overview of N-Heterocyclic Carbenes. Nature 2014, 510, 485-496. [CrossRef] 
2. Nesterov, V.; Reiter, D.; Bag, P.; Frisch, P.; Holzner, R.; Porzelt, A.; Inoue, S. NHCs in Main Group Chemistry. Chem. Rev. 2018, 118, 9678-9842. [CrossRef]

3. Danopoulos, A.A.; Simler, T.; Braunstein, P. N-Heterocyclic Carbene Complexes of Copper, Nickel, and Cobalt. Chem. Rev. 2019, 119, 3730-3961. [CrossRef]

4. Scholl, M.; Ding, S.; Lee, C.W.; Grubbs, R.H. Synthesis and Activity of a New Generation of Ruthenium-Based Olefin Metathesis Catalysts Coordinated with 1,3-Dimesityl-4,5-dihydroimidazol-2-ylidene Ligands. Org. Lett. 1999, 1, 953-956. [CrossRef]

5. Garber, S.B.; Kingsbury, J.S.; Gray, B.L.; Hoveyda, A.H. Efficient and Recyclable Monomeric and Dendritic Ru-Based Metathesis Catalysts. J. Am. Chem. Soc. 2000, 122, 8168-8179. [CrossRef]

6. Vougioukalakis, G.C.; Grubbs, R.H. Ruthenium-Based Heterocyclic Carbene-Coordinated Olefin Metathesis Catalysts. Chem. Rev. 2010, 110, 1746-1787. [CrossRef]

7. Montgomery, T.P.; Johns, A.M.; Grubbs, R.H. Recent Advancements in Stereoselective Olefin Metathesis Using Ruthenium Catalysts. Catalysts 2017, 7, 87. [CrossRef]

8. de Fremont, P.; Marion, N.; Nolan, S.P. Carbenes: Synthesis, properties, and organometallic chemistry. Coord. Chem. Rev. 2009, 253, 862-892. [CrossRef]

9. Wang, W.; Cui, L.; Sun, P.; Shi, L.; Yue, C.; Li, F. Reusable N-Heterocyclic Carbene Complex Catalysts and Beyond: A Perspective on Recycling Strategies. Chem. Rev. 2018, 118, 9843-9929. [CrossRef]

10. Doddi, A.; Peters, M.; Tamm, M. N-Heterocyclic Carbene Adducts of Main Group Elements and Their Use as Ligands in Transition Metal Chemistry. Chem. Rev. 2019, 119, 6994-7112. [CrossRef]

11. Crudden, C.M.; Allen, D.P. Stability and reactivity of N-heterocyclic carbene complexes. Coord. Chem. Rev. 2004, 248, 2247-2273. [CrossRef]

12. Liddle, S.T.; Edworthy, I.S.; Arnold, P.L. Anionic tethered N-heterocyclic carbene chemistry. Chem. Soc. Rev. 2007, 36, 1732-1744. [CrossRef]

13. Arnold, P.L.; Casely, I.J. F-Block N-Heterocyclic Carbene Complexes. Chem. Rev. 2009, 109, 3599-3611. [CrossRef]

14. Peris, E. Smart N-Heterocyclic Carbene Ligands in Catalysis. Chem. Rev. 2018, 118, 9988-10031. [CrossRef]

15. Meng, G.; Kakalis, L.; Nolan, S.P.; Szostak, M. A simple ${ }^{1} \mathrm{H}$ NMR method for determining the $\sigma$-donor properties of N-heterocyclic carbenes. Tetrahedron Lett. 2019, 60, 378-381. [CrossRef]

16. Zeimentz, P.M.; Arndt, S.; Elvidge, B.R.; Okuda, J. Cationic Organometallic Complexes of Scandium, Yttrium, and the Lanthanoids. Chem. Rev. 2006, 106, 2404-2433. [CrossRef]

17. Zimmermann, M.; Anwander, R. Homoleptic Rare-Earth Metal Complexes Containing Ln-C $\sigma$-Bonds. Chem. Rev. 2010, 110, 6194-6259. [CrossRef]

18. Rodrigues, A.-S.; Kirillov, E.; Carpentier, J.-F. Group 3 and 4 single-site catalysts for stereospecific polymerization of styrene. Coord. Chem. Rev. 2008, 252, 2115-2136. [CrossRef]

19. Rodrigues, A.-S.; Carpentier, J.-F. Groups 3 and 4 single-site catalysts for styrene-ethylene and styrene- $\alpha$-olefin copolymerization. Coord. Chem. Rev. 2008, 252, 2137-2154. [CrossRef]

20. Nishiura, M.; Hou, Z. Novel polymerization catalysts and hydride clusters from rare-earth metal dialkyls. Nat. Chem. 2010, 2, 257-268. [CrossRef]

21. Zhang, Z.; Cui, D.; Wang, B.; Liu, B.; Yang, Y. Polymerization of 1,3-Conjugated Dienes with Rare-Earth Metal Precursors. Struct. Bond. 2010, 137, 49-108.

22. Nishiura, M.; Guo, F.; Hou, Z. Half-Sandwich Rare-Earth-Catalyzed Olefin Polymerization, Carbometalation, and Hydroarylation. Acc. Chem. Res. 2015, 48, 2209-2220. [CrossRef]

23. Jothieswaran, J.; Fadlallah, S.; Bonnet, F.; Visseaux, M. Recent Advances in Rare Earth Complexes Bearing Allyl Ligands and Their Reactivity towards Conjugated Dienes and Styrene Polymerization. Catalysts 2017, 7, 378. [CrossRef]

24. Edelmanna, F.T. Lanthanide amidinates and guanidinates in catalysis and materials science: A continuing success story. Chem. Soc. Rev. 2012, 41,7657-7672. [CrossRef]

25. Carpentier, J.-F. Rare-Earth Complexes Supported by Tripodal Tetradentate Bis(phenolate) Ligands: A Privileged Class of Catalysts for Ring-Opening Polymerization of Cyclic Esters. Organometallics 2015, 34, 4175-4189. [CrossRef]

26. Lyubov, D.M.; Tolpygin, A.O.; Trifonov, A.A. Rare-earth metal complexes as catalysts for ring-opening polymerization of cyclic esters. Coord. Chem. Rev. 2019, 392, 83-145. [CrossRef] 
27. Huang, J.; Liu, Z.; Cui, D.; Liu, X. Precisely Controlled Polymerization of Styrene and Conjugated Dienes by Group 3 Single-Site Catalysts. ChemCatChem 2018, 10, 42-61. [CrossRef]

28. Wang, C.; Luo, G.; Nishiura, M.; Song, G.; Yamamoto, A.; Luo, Y.; Hou, Z. Heteroatom-assisted olefin polymerization by rare-earth metal catalysts. Sci. Adv. 2017, 3, e1701011. [CrossRef]

29. Wang, H.; Yang, Y.; Nishiura, M.; Higaki, Y.; Takahara, A.; Hou, Z. Synthesis of Self-Healing Polymers by Scandium-Catalyzed Copolymerization of Ethylene and Anisylpropylenes. J. Am. Chem. Soc. 2019, 141, 3249-3257. [CrossRef]

30. Wang, H.; Zhao, Y.; Nishiura, M.; Yang, Y.; Luo, G.; Luo, Y.; Hou, Z. Scandium-Catalyzed Regio- and Stereoselective Cyclopolymerization of Functionalized $\alpha, \omega$-Dienes and Copolymerization with Ethylene. J. Am. Chem. Soc. 2019, 141, 12624-12633. [CrossRef]

31. Chen, J.; Gao, Y.; Wang, B.; Lohr, T.L.; Marks, T.J. Scandium-Catalyzed Self-Assisted Polar Comonomer Enchainment in Ethylene Polymerization. Angew. Chem. Int. Ed. 2017, 56, 15964-15968. [CrossRef] [PubMed]

32. Liu, D.; Yao, C.; Wang, R.; Wang, M.; Wang, Z.; Wu, C.; Lin, F.; Li, S.; Wan, X.; Cui, D. Highly Isoselective Coordination Polymerization of ortho-Methoxystyrene with $\beta$-Diketiminato Rare-Earth-Metal Precursors. Angew. Chem. Int. Ed. 2015, 54, 5205-5209. [CrossRef] [PubMed]

33. Liu, D.; Wang, M.; Wang, Z.; Wu, C.; Pan, Y.; Cui, D. Stereoselective Copolymerization of Unprotected Polar and Nonpolar Styrenes by anYttrium Precursor: Control of Polar-Group Distribution and Mechanism. Angew. Chem. Int. Ed. 2017, 56, 2714-2719. [CrossRef]

34. Liu, B.; Qiao, K.; Fang, J.; Wang, T.; Wang, Z.; Liu, D.; Xie, Z.; Maron, L.; Cui, D. Mechanism and Effect of Polar Styrenes on Scandium-Catalyzed Copolymerization with Ethylene. Angew. Chem. Int. Ed. 2018, 57, 14896-14901. [CrossRef]

35. Unless otherwise specified, the Ln-NHCs complexes reported in this review are air and moisture sensitive.

36. Rieb, J.; Schaper, L.-A.; Tosh, E.; Herrmann, W.A.; Kühn, F.E. Rare Earth Metal Complexes with N-Heterocyclic Carbenes. In N-Heterocyclic Carbenes: From Laboratory Curiosities to Efficient Synthetic Tools, 2nd ed.; Díez-González, S., Ed.; RSC: Cambridge, UK, 2017; Chapter 6; pp. 238-267.

37. Schumann, H.; Glanz, M.; Winterfeld, J.; Hemling, H.; Kuhn, N.; Kratz, T. Organolanthanoid-CarbeneAdducts. Angew. Chem. Int. Ed. Engl. 1994, 33, 1733-1734. [CrossRef]

38. Schumann, H.; Glanz, M.; Winterfeld, J.; Hemling, H.; Kuhn, N.; Kratz, T. Carben-Addukte des zweiwertigen Samariums und Ytterbiums. Chem. Ber. 1994, 127, 2369-2372. [CrossRef]

39. Arduengo, A.J., III; Tamm, M.; McLain, S.J.; Calabrese, J.C.; Davidson, F.; Marshall, W.J. Carbene-Lanthanide Complexes. J. Am. Chem. Soc. 1994, 116, 7927-7928. [CrossRef]

40. Wolfgang, W.A.; Munck, F.C.; Artus, G.R.J.; Runte, O.; Anwander, R. 1,3-Dimethylimidazolin-2-ylidene Carbene Donor Ligation in Lanthanide Silylamide Complexes. Organometallics 1997, 16, 682-688.

41. Meermann, C.; Gerstberger, G.; Spiegler, M.; Törnroos, K.W.; Anwander, R. Donor and ate-Coordination in Rare-Earth Metal Bis(dimethylsilyl)amide Complexes. Eur. J. Inorg. Chem. 2008, 12, 2014-2023. [CrossRef]

42. Fegler, W.; Spaniol, T.P.; Okuda, J. Trimethylsilylmethyl complexes of the rare-earth metals with sterically hindered N-heterocyclic carbene ligands: Adduct formation and C-H bond activation. Dalton Trans. 2010, 39, 6774-6779. [CrossRef]

43. Fegler, W.; Saito, T.; Mashima, K.; Spaniol, T.P.; Okuda, J. C-H bond activation of N-heterocyclic carbene IMes by rare-earth metal alkyl complexes. J. Organomet. Chem. 2010, 695, 2794-2797. [CrossRef]

44. Pan, Y.; Xu, T.; Ge, Y.-S.; Lu, X.-B. N-heterocyclic Carbene Scandium Complexes: Synthesis, Structure, and Catalytic Performance for $\alpha$-Olefin Polymerization and Copolymerization with 1,5-Hexadiene. Organometallics 2011, 30, 5687-5694. [CrossRef]

45. Pan, Y.; Zhao, A.; Li, Y.; Li, W.; So, Y.-M.; Yan, X.; He, G. Bis(oxazoline)-derived N-heterocyclic carbine ligated rare-earth metal complexes: Synthesis, structure, and polymerization performance. Dalton Trans. 2018, 47, 13815-13823. [CrossRef]

46. Xie, W.; Hu, H.; Cui, C. [(NHC) $\left.\mathrm{Yb}\left\{\mathrm{N}\left(\mathrm{SiMe}_{3}\right)_{2}\right\}_{2}\right]$-Catalyzed Cross-Dehydrogenative Coupling of Silanes with Amines. Angew. Chem. Int. Ed. 2012, 51, 11141-11144. [CrossRef]

47. Yuan, J.; Hu, H.; Cui, C. N-Heterocyclic Carbene-Ytterbium Amideasa Recyclable Homogeneous Precatalyst for Hydrophosphination of Alkenes and Alkynes. Chem. Eur. J. 2016, 22, 5778-5785. [CrossRef]

48. Chang, K.; Dong, Y.; Xu, X. Dihydrogen activation by intermolecular rare-earth aryloxide/N-heterocyclic carbene Lewis pairs. Chem. Commun. 2019, 55, 12777-12780. [CrossRef] 
49. Rottschafer, D.; Blomeyer, S.; Neumann, B.; Stammler, H.-G.; Ghadwal, R. Silylene-Functionalized N-Heterocyclic Carbene (Si-NHC). Chem. Eur. J. 2018, 24, 380-387. [CrossRef]

50. Rottschafer, D.; Ebeler, F.; Strothmann, T.; Neumann, B.; Stammler, H.-G.; Mix, A.; Ghadwal, R. The Viability of C5-Protonated- and C4, C5-Ditopic Carbanionic Abnormal NHCs: A New Dimension in NHC Chemistry. Chem. Eur. J. 2018, 24, 3716-3720. [CrossRef]

51. Roth, T.; Vasilenko, V.; Benson, C.; Wadepohl, H.; Wright, D.; Gade, L. Extending N-heterocyclic carbene ligands into the third dimension: A new type of hybrid phosphazane/NHC system. Chem. Sci. 2015, 6, 2506-2510. [CrossRef]

52. Seed, A.; Gregson, M.; Tuna, F.; Chilton, N.; Wooles, A.; McInnes, E.; Liddle, S. Rare-Earth- and Uranium-Mesoionic Carbenes: A New Class of f-Block Carbene Complex Derived from an N-Heterocyclic Olefin. Angew. Chem. Int. Ed. 2017, 56, 11534-11538. [CrossRef]

53. Arnold, P.L.; Mungur, S.; Blake, A.; Wilson, C. Anionic Amido N-Heterocyclic Carbenes: Synthesis of Covalently Tethered Lanthanide-Carbene Complexes. Angew. Chem. Int. Ed. 2003, 42, 5981-5984. [CrossRef] [PubMed]

54. Patel, D.; Liddle, S.; Mungur, S.A.; Rodden, M.; Blake, A.J.; Arnold, P.L. Bifunctional yttrium(III) and titanium(IV) NHC catalysts for lactide polymerization. Chem. Commun. 2006, 10, 1124-1126. [CrossRef] [PubMed]

55. Arnold, P.L.; Casely, I.; Turner, Z.; Carmichael, C. Functionalised Saturated-Backbone Carbene Ligands: Yttrium and Uranyl Alkoxy-Carbene Complexes and Bicyclic Carbene-Alcohol Adducts. Chem. Eur. J. 2008, 14, 10415-10422. [CrossRef] [PubMed]

56. Turner, Z.; Bellabarba, R.; Tooze, R.; Arnold, P.L. Addition-Elimination Reactions across the M-C Bond of Metal N-Heterocyclic Carbenes. J. Am. Chem. Soc. 2010, 132, 4050-4051. [CrossRef]

57. Arnold, P.L.; Turner, Z.; Bellabarba, R.; Tooze, R. Carbon-Silicon and Carbon-Carbon Bond Formation by Elimination Reactions at Metal N-Heterocyclic Carbene Complexes. J. Am. Chem. Soc. 2011, 133, 11744-11756. [CrossRef]

58. Arnold, P.L.; McMaster, J.; Liddle, S. An unsupported transition metal-lanthanide bond; synthesis and crystal structure of an Nd-Fe amido N-heterocyclic carbene complex. Chem. Commun. 2009, 7, 818-820. [CrossRef]

59. Liddle, S.; Arnold, P.L. Synthesis of Heteroleptic Cerium(III) Anionic Amido-Tethered N-Heterocyclic Carbene Complexes. Organometallics 2005, 24, 2597-2605. [CrossRef]

60. Arnold, P.L.; Marr, I.; Zlatogorsky, S.; Bellabarba, R.; Tooze, R. Activation of carbon dioxide and carbon disulfide by a scandium N-heterocyclic carbene complex. Dalton Trans. 2014, 43, 34-37. [CrossRef]

61. Arnold, P.L.; Kerr, R.; Weetman, C.; Docherty, S.; Rieb, J.; Cruickshank, F.; Wang, K.; Jandl, C.; McMullon, M.; Pöthig, A.; et al. Selective and catalytic carbon dioxide and heteroallene activation mediated by cerium N-heterocyclic carbene complexes. Chem. Sci. 2018, 9, 8035-8045. [CrossRef]

62. Wang, Z.; Sun, H.; Yao, H.; Yao, Y.-M.; Shen, Q.; Zhang, Y. Bis-aryloxo-functionalized NHC complexes of ytterbium(III): Syntheses and structures of $\mathrm{Yb}\left[\mathrm{O}-4,6-{ }^{-} \mathrm{Bu}_{2}-\mathrm{C}_{6} \mathrm{H}_{2}-2-\mathrm{CH}_{2}\{\mathrm{C}(\mathrm{RNCHCHN})\}\right]_{2} \mathrm{~N}\left({ }^{\mathrm{i}} \mathrm{Pr}\right)_{2}\left(\mathrm{R}={ }^{\mathrm{i}} \mathrm{Pr}\right.$, Me). J. Organomet. Chem. 2006, 691, 3383-3390. [CrossRef]

63. Wang, Z.; Sun, H.; Yao, H.; Shen, Q.; Zhang, Y. Mono- and Tris-Phenoxo-Tethered N-Heterocyclic Carbene Yttrium Complexes: Syntheses and Molecular Structures. Organometallics 2006, 25, 4436-4438. [CrossRef]

64. Yao, H.; Zhang, J.; Zhang, Y.; Sun, H.; Shen, Q. Synthesis of Cationic N-Heterocyclic Carbene Lanthanide Bromide and the Influence of N-Heterocyclic Carbene and Lanthanide Metals. Organometallics 2010, 29, 5841-5846. [CrossRef]

65. Wang, B.; Wang, D.; Cui, D.; Gao, W.; Tang, T.; Chen, X.; Jing, X. Synthesis of the First Rare Earth Metal Bis(alkyl)s Bearing an Indenyl Functionalized N-Heterocyclic Carbene. Organometallics 2007, 26, 3167-3172. [CrossRef]

66. Wang, B.; Cui, D.; Lv, K. Highly 3,4-Selective Living Polymerization of Isoprene with Rare Earth Metal Fluorenyl N-Heterocyclic Carbene Precursors. Macromolecules 2008, 41, 1983-1988. [CrossRef]

67. Wang, B.; Tang, T.; Li, Y.; Cui, D. Copolymerization of ethylene with norbornene catalyzed by cationic rare earth metal fluorenyl functionalized N-heterocyclic carbene complexes. Dalton Trans. 2009, 41, 8963-8969. [CrossRef]

68. Yao, C.; Wu, C.; Wang, B.; Cui, D. Copolymerization of Ethylene with 1-Hexene and 1-Octene Catalyzed by Fluorenyl N-Heterocyclic Carbene Ligated Rare-Earth Metal Precursors. Organometallics 2013, 32, 2204-2209. [CrossRef] 
69. Li, S.; Wang, M.; Cui, D. Copolymerization of ethylene with styrene catalyzed by a scandium catalyst. Polym. Chem. 2018, 9, 4757-4763. [CrossRef]

70. Li, S.; Liu, D.; Wang, Z.; Cui, D. Development of Group 3 Catalysts for Alternating Copolymerization of Ethylene and Styrene Derivatives. ACS Catal. 2018, 8, 6086-6093. [CrossRef]

71. Hu, Y.; Miyake, G.; Wang, B.; Cui, D.; Chen, E.Y.-X. ansa-Rare-Earth-Metal Catalysts for Rapid and Stereoselective Polymerization of Renewable Methylene Methylbutyrolactones. Chem. Eur. J. 2012, 18, 3345-3354. [CrossRef]

72. Yao, C.; Xie, H.; Cui, D. Highly 3,4-selective living polymerization of 2-phenyl-1,3-butadiene with amidino N-heterocyclic carbene ligated rare-earth metal bis(alkyl) complexes. RSC Adv. 2015, 5, 93507-93512. [CrossRef]

73. Shi, R.; Zhang, Z.; Hu, X. Nickamine and Analogous Nickel Pincer Catalysts for Cross-Coupling of Alkyl Halides and Hydrosilylation of Alkenes. Acc. Chem. Res. 2019, 52, 1471-1483. [CrossRef] [PubMed]

74. Junge, K.; Papa, V.; Beller, M. Cobalt-Pincer Complexes in Catalysis. Chem. Eur. J. 2019, 25, $122-143$. [CrossRef] [PubMed]

75. Alig, L.; Fritz, M.; Schneider, S. First-Row Transition Metal (De)Hydrogenation Catalysis Based on Functional Pincer Ligands. Chem. Rev. 2019, 119, 2681-2751. [CrossRef] [PubMed]

76. Mukherjee, A.; Milstein, D. Homogeneous Catalysis by Cobalt and Manganese Pincer Complexes. ACS Catal. 2018, 8, 11435-11469. [CrossRef]

77. Polukeev, A.; Wendt, O. Iridium complexes with aliphatic, non-innocent pincer ligands. J. Organomet. Chem. 2018, 867, 33-50. [CrossRef]

78. Feichtner, K.-S.; Gessner, V. Cooperative bond activation reactions with carbene complexes. Chem. Commun. 2018, 54, 6540-6553. [CrossRef] [PubMed]

79. Lv, K.; Cui, D. Tridentate CCC-Pincer Bis(carbene)-Ligated Rare-Earth Metal Dibromides. Synthesis and Characterization. Organometallics 2008, 27, 5438-5440. [CrossRef]

80. Lv, K.; Cui, D. CCC-Pincer Bis(carbene) Lanthanide Dibromides. Catalysis on Highly cis-1,4-Selective Polymerization of Isoprene and Active Species. Organometallics 2010, 29, 2987-2993. [CrossRef]

81. Gu, X.; Zhu, X.; Wei, Y.; Wang, S.; Zhou, S.; Zhang, G.; Mu, X. CNC-Pincer Rare-Earth Metal Amido Complexes with a Diarylamido Linked Biscarbene Ligand: Synthesis, Characterization, and Catalytic Activity. Organometallics 2014, 33, 2372-2379. [CrossRef]

82. Gu, X.; Zhang, L.; Zhu, X.; Wang, S.; Zhou, S.; Wei, Y.; Zhang, G.; Mu, X.; Huang, Z.; Hong, D.; et al. Synthesis of Bis(NHC)-Based CNC-Pincer Rare-Earth-Metal Amido Complexes and Their Application for the Hydrophosphination of Heterocumulenes. Organometallics 2015, 34, 4553-4559. [CrossRef]

83. Yao, H.; Zhang, Y.; Sun, H.; Shen, Q. Anionic Lanthanide Complexes Bearing a Bis(phenoxy)-Functionalized N-Heterocyclic Carbene Ligand: Syntheses and Molecular Structures. Eur. J. Inorg. Chem. 2009, 13, 1920-1925. [CrossRef]

84. Zhang, M.; Ni, X.; Shen, Z. Synthesis of Bimetallic Bis(phenolate) N-Heterocyclic Carbene Lanthanide Complexes and Their Applications in the Ring-Opening Polymerization of L-Lactide. Organometallics 2014, 33, 6861-6867. [CrossRef]

85. Zhang, M.; Zhang, J.; Ni, X.; Shen, Z. Bis(phenolate) N-heterocyclic carbene rare earth metal complexes: Synthesis, characterization and applications in the polymerization of $n$-hexyl isocyanate. RSC Adv. 2015, 5, 83295-83303. [CrossRef]

86. Zhang, J.; Zhang, M.; Bai, T.; Ni, X.; Shen, Z. Synthesis and characterization of heterobimetallic organo rare earth complexes bearing aryloxide-N-heterocyclic carbene ligands. J. Organomet. Chem. 2017, 843, 1-6. [CrossRef]

(C) 2020 by the authors. Licensee MDPI, Basel, Switzerland. This article is an open access article distributed under the terms and conditions of the Creative Commons Attribution (CC BY) license (http://creativecommons.org/licenses/by/4.0/). 